\title{
B Cells Promote Tumor Immunity against B16F10 Melanoma
}

Tadahiro Kobayashi, ${ }^{*}$ Yasuhito Hamaguchi, ${ }^{*}$ Minoru Hasegawa, ${ }^{\dagger}$ Manabu Fujimoto, ${ }^{\ddagger}$ Kazuhiko Takehara, ${ }^{\star}$ and Takashi Matsushita*

From the Department of Dermatology, * Faculty of Medicine, Institute of Medical, Pharmaceutical, and Health Sciences, Kanazawa University, Kanazawa; the Department of Dermatology, ${ }^{\dagger}$ University of Fukui, Fukui; and the Department of Dermatology, ${ }^{\ddagger}$ Faculty of Medicine, University of Tsukuba, Tsukuba, Japan

Accepted for publication July $15,2014$.

Address correspondence to Takashi Matsushita, M.D., Ph.D., Department of Dermatology, Faculty of Medicine, Institute of Medical, Pharmaceutical, and Health Sciences, Kanazawa University, 13-1 Takaramachi, Kanazawa, Ishikawa 920-8641, Japan. E-mail: t-matsushita@med. kanazawa-u.ac.jp.

\begin{abstract}
$B$ cells are known to be critical mediators of tumor immunity; however, the mechanisms through which they exert this function remain unclear. B-cell linker protein (BLNK) is an essential component of the B-cell antigen receptor signaling machinery and is required for B-cell development, as evidenced by $B L N K$-deficient $\left(B L N K^{-/-}\right)$mice, in which the development and function of $B$ cells are severely impaired. Herein, we evaluated the role of B cells in the development of tumor immunity against B16F10 melanoma using $B L N K^{-1-}$ mice. B16F10 melanoma grew more aggressively in $B L N K^{-/-}$mice, resulting in a twofold increase in tumor volume compared with wild-type mice. As predicted, tumor-infiltrating B-cell numbers were decreased in $B L N K^{-/-}$mice. Paradoxically, tumor-infiltrating T-cell numbers were decreased in $B L N K^{-/-}$mice, although inguinal lymph node T-cell numbers were increased. Adoptive transfer of $B$ cells from wild-type mice into $B L N K^{-/-}$mice attenuated B16F10 melanoma growth, with increasing numbers of $B$ and $T$ cells infiltrating into tumors. In addition, percentages of interferon- $\gamma-$ and tumor necrosis factor- $\alpha$-producing tumor-infiltrating $T$ cells were restored. Taken together, our study supports the concept that B cells enhance tumor immunity against B16F10 melanoma by promoting T-cell infiltration into tumors and cytokine production within the tumor microenvironment. (Am J Pathol 2014, 184: 3120-3129; http://dx.doi.org/10.1016/j.ajpath.2014.07.003)
\end{abstract}

In addition to providing humoral immunity, B cells have multiple other functions, including antigen $(\mathrm{Ag})$ presentation to and activation of T cells. ${ }^{1}$ It is also widely recognized that certain B-cell subpopulations exhibit potent regulatory properties and are involved in immune pathological conditions, such as autoimmunity and malignancy. ${ }^{2,3}$ For example, in murine autoimmune models, adoptive transfer of B cells can ameliorate chronic inflammatory responses, even when disease is already established. ${ }^{2,4}$

In tumor immunity, B cells can exert both negative and positive effects. For example, tumor immunity against B16F10 melanoma, EL4 thymoma, and MC38 colon carcinoma was found to be enhanced in B-cell-deficient $\mu \mathrm{MT}$ mice compared with wild-type (WT) controls. ${ }^{5}$ Thus, both $\mathrm{CD}^{+}{ }^{+} \mathrm{T}$-cell priming and anti-tumor type 1 helper $\mathrm{T}$-cell (Th1) cytokine production as well as $\mathrm{CD}^{+}$cytotoxic $\mathrm{T}$ lymphocyte responses were enhanced in $\mu \mathrm{MT}$ mice. ${ }^{6}$ Notably, reconstitution of $\mu \mathrm{MT}$ mice with WT B cells abrogated tumor resistance. ${ }^{5}$ However, a caveat of studies conducted in $\mu \mathrm{MT}$ mice is that there are severe immune system abnormalities and skewing toward Th1 responses. ${ }^{7,8}$

$\mathrm{B}$ cells are also capable of promoting anti-tumor immunity by functioning as antigen-presenting cells (APCs) and/or via cross presentation of $\mathrm{Ag}$ to other APCs to regulate cellular immune responses. ${ }^{9,10}$ In addition, B cells activated by CD40 ligand (CD40L) can induce an Ag-specific anti-tumor immune response by $\mathrm{CD}^{+}{ }^{+}$T cells. ${ }^{9}$ Furthermore, depletion of mature $B$ cells using an anti-CD20 monoclonal antibody (mAb) results in enhanced $\mathrm{B} 16 \mathrm{~F} 10$ melanoma tumor growth that was correlated with impaired activation of $\mathrm{CD}^{+}$and $\mathrm{CD} 8^{+}$ effector-memory $\mathrm{T}$ cells and inflammatory and cytotoxic cytokine-secreting T cells. B-cell depletion was also shown to impair tumor Ag-specific CD8 ${ }^{+}$T-cell proliferation. ${ }^{11}$ Thus,

Supported by Ministry of Education, Culture, Sports, Science, and Technology of Japan grants-in-aid and Ministry of Health, Labor, and Welfare of Japan grants-in-aid.

Disclosures: None declared. 
$\mu \mathrm{MT}$ mice and anti-CD20 mAb-treated mice both lack mature $\mathrm{B}$ cells, although divergent tumor responses are elicited in these models.

B-cell linker protein (BLNK) is a B-cell-specific adaptor molecule that contains multiple protein-binding motifs. Disturbed expression of BLNK results in severely altered development and function of B cells in mice and in human patients. ${ }^{12-15}$ In $B L N K$-deficient $\left(B L N K^{-1-}\right)$ mice, B cells are impaired in their ability to produce the immunosuppressive cytokine IL-10 and develop more severe contact hypersensitivity and experimental autoimmune encephalomyelitis compared with WT mice. IL-10 message levels in B cells after contact hypersensitivity or experimental autoimmune encephalomyelitis induction are significantly decreased in $B L N K^{-l-}$ mice compared with WT mice, whereas interferon (IFN)- $\gamma$, IL-2, IL-4, and IL-6 mRNA expression levels are not significantly different. ${ }^{16}$ Thus, $B L N K^{-1-}$ mice are a good model for the investigation of B-cell function in tumor immunity. Herein, we show that B cells enhance tumor immunity by promoting $\mathrm{CD} 4^{+}$and $\mathrm{CD}^{+} \mathrm{T}$-cell infiltration into tumors and cytokine production by these cells in the tumor microenvironment.

\section{Materials and Methods}

\section{Mice and Cell Culture}

Female C57BL/6 mice (9 to 12 weeks old) were purchased from SLC (Shizuoka, Japan); BLNK ${ }^{-1-}$ mice on the C57BL/ 6 background were from Jackson Laboratory (Bar Harbor, $\mathrm{ME}$ ). All mice were housed and cared for in a pathogen-free barrier facility. All studies and procedures were approved by the Animal Committees of Kanazawa University, Institute of Medical, Pharmaceutical, and Health Sciences (Kanazawa, Japan). B16F10 melanoma cells were purchased from ATCC (Manassas, VA). Cells were cultured at $37^{\circ} \mathrm{C}$ in $5 \%$ $\mathrm{CO}_{2}$ in Dulbecco's modified Eagle's medium supplemented with fetal bovine serum and penicillin/streptomycin. The cells were passaged twice a week with trypsin. All cell culture reagents were obtained from Sigma-Aldrich (St. Louis, MO). Only early passages of the cell line were used in experiments.

\section{In Vivo Tumor Growth}

B16F10 cells $\left(1.0 \times 10^{6}\right)$ in $100 \mu \mathrm{L}$ sterile phosphatebuffered saline (PBS) were injected s.c. into the shaved right flank of anesthetized mice. Tumor growth was monitored on days $4,7,11,14,18$, and 21 after tumor injection. The tumor volume was calculated using the following equation:

$$
V=4 \pi\left(L_{1} \times L_{2}^{2}\right) / 3,
$$

where $V=$ volume $\left(\mathrm{mm}^{3}\right), L_{1}=$ longest diameter $(\mathrm{mm})$, and $L_{2}=$ shortest diameter $(\mathrm{mm})$.

\section{Histological Examination and IHC}

For immunohistochemical (IHC) staining of CD3 and B220, s.c. tumors harvested with surrounding circumference skin on day 11 after inoculation, freshly dissected spleens, and freshly dissected inguinal lymph nodes were fixed in 3.5\% paraformaldehyde and then paraffin embedded. Sections (4 $\mu \mathrm{m}$ thick) were then incubated with rat mAbs specific for mouse CD3 (CD3-12; AbD Serotic, Oxford, UK) and B220 (RA3-6B2; BD Biosciences, San Jose, CA).

For IHC staining of CD4, CD8, Foxp3, and NK1.1, s.c. tumors harvested with surrounding circumference skin on day 11 after inoculation, freshly dissected spleens, and freshly dissected inguinal lymph nodes were covered with Tissue-Tek OCT compound (SAKURA Finetek USA, Torrance, CA) and quickly frozen in liquid nitrogen. Frozen sections ( $4 \mu \mathrm{m}$ thick) were fixed in acetone and incubated with rat $\mathrm{mAbs}$ specific for mouse CD4 (RM4-5), CD8a (53-6.7; BD Biosciences), Foxp3 (FJK-16s; eBioscience, San Diego, CA), and NK1.1 (PK136; BioLegend, San Diego, CA).

Sections of spleens and inguinal lymph nodes were developed with $3,3^{\prime}$-diaminobendine tetrahydrochloride to stain targeted cells brown and then counterstained with hematoxylin. Sections of s.c. tumors were developed with New Fuchsin (Daco Japan, Tokyo, Japan) to stain targeted cells red, and thus, differentiate from brown melanin pigment, and then counterstained with hematoxylin. The numbers of stained cells in 10 high-power microscopic fields $\left(0.07 \mathrm{~mm}^{2}\right)$ were averaged, and each section was examined independently by two investigators in a blind manner (T.K. and T.M.).

\section{Flow Cytometry}

The following mAbs were used: fluorescein isothiocyanate-, phosphatidylethanolamine-, PerCP-Cy5.5-, APC-, APCCy7-, or Pacific Blue-conjugated mAbs to mouse B220 (RA3-6B2; BD Biosciences), CD3e (145-2C11), CD4 (RM4-5), CD25 (PC61.5; BioLegend), CD8a (53-6.7), NK1.1 (PK136), and Foxp3 (FJK-16s; eBioscience). LIVE/ DEAD Fixable Aqua Dead Cell Stain (Invitrogen, Carlsbad, CA) was used to detect dead cells.

Single-cell suspensions of splenocytes, inguinal lymph nodes, and tumor-infiltrating lymphocytes were stained for 20 minutes using mAbs at predetermined optimal concentrations for multicolor immunofluorescence analysis using a FACSCanto II flow cytometer (BD Biosciences). ${ }^{17}$ Data were analyzed using FlowJo software version 8.8.7 (Tree Star, Ashland, OR).

\section{Intracellular Cytokine Staining}

For detection of cytokine production, $\mathrm{T}$ cells were stimulated for 4 hours with $50 \mathrm{ng} / \mathrm{mL}$ phorbol myristate acetate (Sigma-Aldrich), $1 \mu \mathrm{g} / \mathrm{mL}$ ionomycin (Sigma-Aldrich), and $3 \mu \mathrm{mol} / \mathrm{L}$ brefeldin A (BioLegend). Natural killer (NK) cells were not stimulated for detection of granzyme B $(\mathrm{GrB})$. 
After cell-surface staining, the cells were washed, fixed, and permeabilized using the Cytofix/Cytoperm Kit (BD Biosciences), followed by staining with anti-IFN- $\gamma$ (XMG1.2), anti-tumor necrosis factor $\alpha$ (TNF- $\alpha$; MP6-XT22), and anti-granzyme B (GB11) mAbs (BioLegend).

\section{Single-Cell Suspensions of Tumor-Infiltrating Lymphocytes for Flow Cytometry}

The s.c. tumors were minced on day 11 after inoculation and then digested in $10 \mathrm{~mL}$ of RPMI 1640 medium-10\% fetal bovine serum containing $2 \mathrm{mg} / \mathrm{mL}$ crude collagenase (SigmaAldrich), $1.5 \mathrm{mg} / \mathrm{mL}$ hyaluronidase (Sigma-Aldrich), and 0.03 $\mathrm{mg} / \mathrm{mL}$ DNase I (Sigma-Aldrich) at $37^{\circ} \mathrm{C}$ for 90 minutes to prepare tumor cell suspensions for flow cytometry. Digested cells were passed through a $70-\mu \mathrm{m}$ cell strainer (BD Biosciences) to generate single-cell suspensions. The cell suspension was centrifuged at $460 \times g$ for 5 minutes. The pellet was resuspended in 70\% Percoll solution (GE Healthcare, Fairfield, CT) and then overlaid with a 37\% Percoll solution (GE Healthcare), followed by centrifugation at $500 \times g$ for 20 minutes at room temperature. The cells were aspirated from the Percoll interface and passed through a $70-\mu \mathrm{m}$ cell strainer (BD Biosciences). Cells were harvested by means of centrifugation and washed with PBS.

\section{Isolation and Adoptive Transfer of B Cells}

B cells were isolated from WT splenocytes using the Pan B Cell Isolation Kit (Miltenyi Biotech, Bergisch Gladbach, Germany) with purities of approximately $95 \%$. After isolation, purified B cells $\left(1.0 \times 10^{7}\right)$ in $500 \mu \mathrm{L}$ sterile PBS were transferred into recipient $B L N K^{-1-}$ mice via i.v. injection through the lateral tail vein 1 day before tumor injection. The control group received PBS.

\section{Statistical Analysis}

All data are shown as means \pm SEM. Statistical significance was determined by using the Student's $t$-test. Survival analysis was performed using a Kaplan-Meier estimate.

\section{Results}

B16F10 Melanoma Growth Is Significantly Increased in $B L N K^{-/-}$Mice

To determine the effect of B cells on tumor immunity against B16F10 melanoma, $B L N K^{-1-}$ and WT mice were injected s.c. with $1.0 \times 10^{6} \mathrm{~B} 16 \mathrm{~F} 10$ melanoma cells in the flank and tumor growth was monitored. B16F10 melanoma growth in $B L N K^{-1-}$ mice was significantly enhanced compared with WT mice. Statistically significant differences in tumor volume between $B L N K^{-1-}$ and WT mice were observed beginning on day 11 after inoculation (Figure 1A), and enhanced tumor growth resulted in decreased survival of
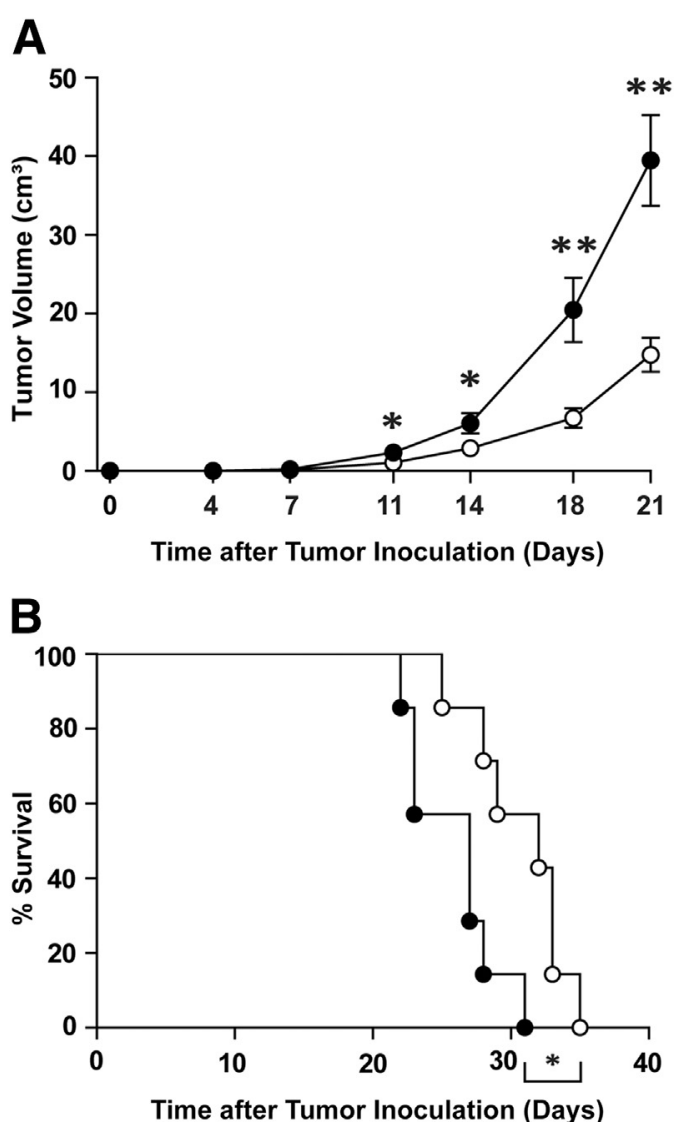

Figure 1 B16F10 melanoma growth increases in $\mathrm{BLNK}^{-/-}$mice. WT (white circles) and $\mathrm{BLNK}^{-1-}$ (black circles) mice were inoculated s.c. in the right flank with $1.0 \times 10^{6} \mathrm{~B} 16 \mathrm{~F} 10$ cells. A: Means \pm SEM tumor volumes on the indicated days after B16F10 melanoma inoculation ( $n=7$ for each group). Significant differences between means for the same days. B: Survival of mice after B16F10 melanoma inoculation ( $n=7$ for each group). Similar results were obtained from three independent experiments. ${ }^{*} P<0.05,{ }^{* *} P<0.01$.

$B L N K^{-1-}$ mice (Figure 1B). Thus, tumor immunity against $\mathrm{B} 16 \mathrm{~F} 10$ melanoma is attenuated in $B L N K^{-/-}$mice.

\section{B-Cell Numbers Are Significantly Decreased in $B L N K^{-/-}$ Mice}

Because BLNK is essential for B-cell development, ${ }^{13}$ we hypothesized that the alteration of B-cell populations in $B L N K^{-1-}$ mice is a factor in the attenuation of tumor immunity. To evaluate lymphocyte populations in $B L N K^{-1-}$ mice, spleen and inguinal lymph node (LN) cells were analyzed by IHC and flow cytometry.

A significant reduction in the number of splenocytes was seen in $B L N K^{-1-}$ mice compared with WT mice $\left[(40.1 \pm 4.8) \times 10^{6}\right.$ cells versus $(124 \pm 12.8) \times 10^{6}$ cells $(P<0.001)]$, whereas numbers of inguinal LN cells did not differ significantly between $B L N K^{-1-}$ and WT mice $\left[(20.9 \pm 1.9) \times 10^{5}\right.$ cells versus $(21.4 \pm 1.4) \times 10^{5}$ cells $(P=0.848)]$. IHC analysis revealed that the number and size of lymphoid follicles and the number of $\mathrm{B} 220^{+}$cells are 
clearly decreased in both the spleen and inguinal LNs of $B L N K^{-1-}$ mice (Figure 2A). On the other hand, the distribution and number of $\mathrm{CD}^{+}$cells in spleen and inguinal LNs of $B L N K^{-1-}$ mice were similar to WT mice (Figure 2B), as were $\mathrm{CD}^{+}, \mathrm{CD}^{+}, \mathrm{Foxp}^{+}$, and NK1.1 ${ }^{+}$cells (data not shown). As shown previously, ${ }^{12}$ flow cytometric analysis of $B L N K^{-1-}$ mice revealed that $\mathrm{B} 220^{+} \mathrm{B}$-cell numbers in the spleen were significantly decreased [by $(69.4 \pm 1.2) \times 10^{6}$ cells, $P<0.001]$ compared with WT mice, and $\mathrm{B} 220^{+}$B-cell numbers in inguinal LNs were also significantly decreased [by $(4.5 \pm 0.4) \times 10^{5}$ cells, $\left.P<0.001\right]$ (Figure 2C). We also assessed T-cell and NK cell numbers in inguinal LNs and spleens. Reflective of the decrease in B-cell numbers, $\mathrm{T}$ and NK cells make up most of the cells in the spleen of $B L N K^{-1-}$ mice, as shown by the increased percentage of $\mathrm{CD}^{+}, \mathrm{CD} 8^{+}$,
$\mathrm{CD} 4{ }^{+} \mathrm{CD} 25^{+} \mathrm{Foxp}^{+}$, and NK1.1 ${ }^{+} \mathrm{CD} 3^{-}$cells compared with WT mice $[39.6 \% \pm 1.1 \%$ versus $20.2 \% \pm 0.9 \%(P<0.001)$, $23.4 \% \pm 0.9 \%$ versus $10.9 \% \pm 0.3 \%(P<0.001)$, $11.7 \% \pm 0.5 \%$ versus $10.2 \% \pm 0.2 \%(P<0.05)$, and $5.0 \% \pm 0.3 \%$ versus $2.1 \% \pm 0.1 \%(P<0.001)$, respectively] (Figure 2, D-F). However, numbers of these cells are lower in $B L N K^{-1-}$ mice than in WT mice, reflecting the decreased cellularity of the $B L N K^{-1-}$ spleen. Numbers of splenic $\mathrm{CD} 4^{+}$, $\mathrm{CD} 8^{+}, \mathrm{CD} 4^{+} \mathrm{CD} 25^{+} \mathrm{Foxp}^{+}$, and $\mathrm{NK} 1.1^{+} \mathrm{CD}^{-}$cells in $B L N K^{-1-}$ mice are decreased by $(9.1 \pm 1.2) \times 10^{6}$ cells $(P<0.001),(4.2 \pm 0.5) \times 10^{6}$ cells $(P<0.001)$, $(0.7 \pm 0.1) \times 10^{6}$ cells $(P<0.001)$, and $(0.7 \pm 0.2) \times 10^{6}$ cells $(P<0.01)$, respectively (Figure $2, \mathrm{D}-\mathrm{F})$.

In contrast, the percentages and numbers of inguinal $\mathrm{LN}$ $\mathrm{CD} 4^{+}, \mathrm{CD} 8^{+}, \mathrm{CD} 4^{+} \mathrm{CD} 25^{+} \mathrm{Foxp}^{+}$, and $\mathrm{NK} 1.1^{+} \mathrm{CD} 3^{-}$cells
A
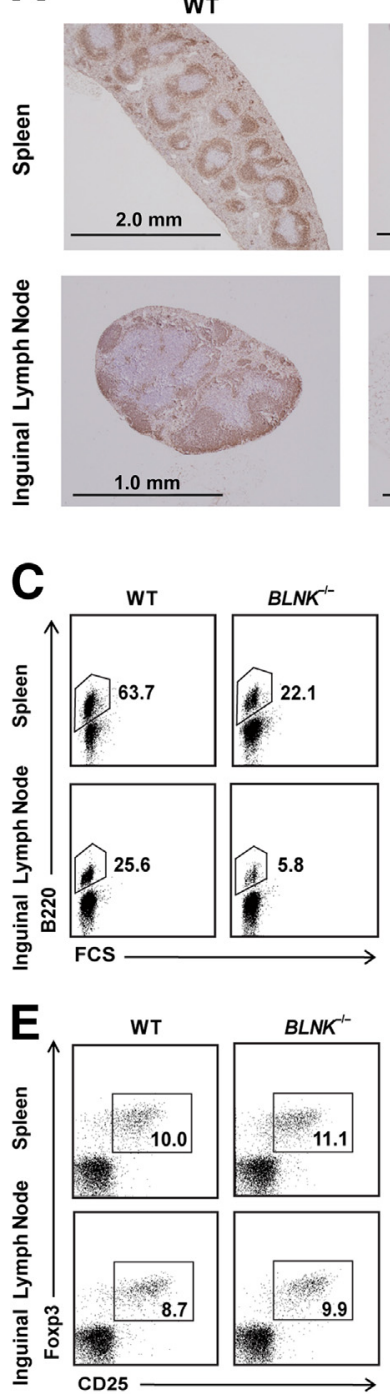

$B L N K^{\prime-}$
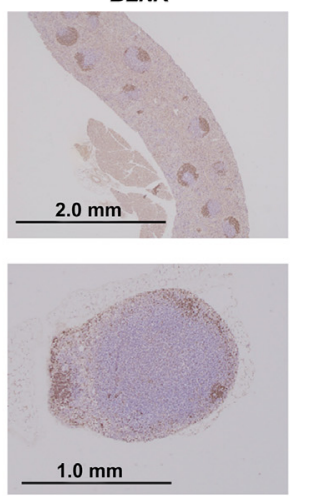

B
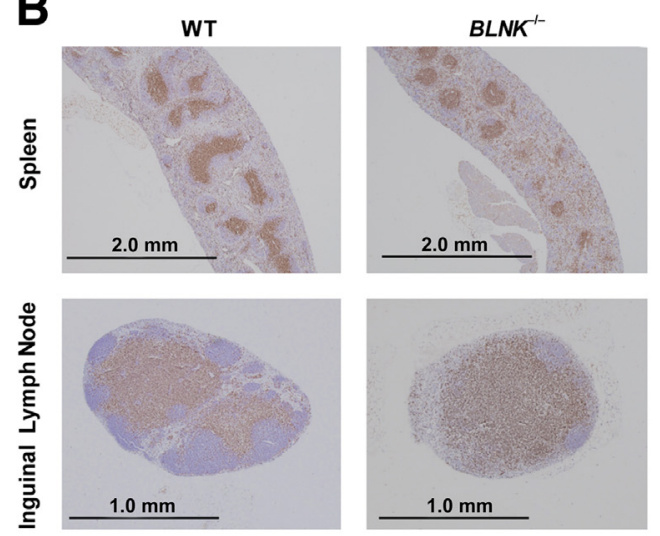
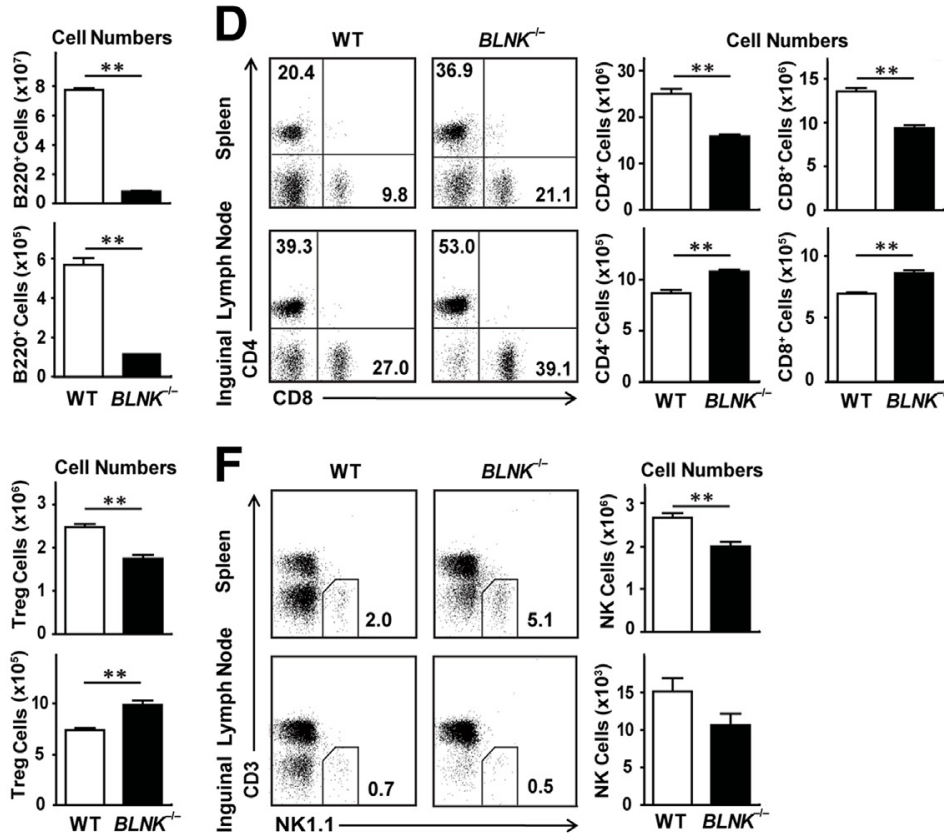

Figure 2 B-cell numbers decrease in $B L N K^{-1-}$ mice. Representative IHC images in spleen and inguinal $\mathrm{LN}$ sections. B220 $0^{+}(\mathbf{A})$ and $\mathrm{CD} 3^{+}(\mathbf{B})$ cells stain brown. The percentages (left, flow cytomerty plots) and numbers (right, bar graphs) of B220 ${ }^{+}(\mathbf{C}), \mathrm{CD}^{+}$and $\mathrm{CD} 8^{+}(\mathbf{D}), \mathrm{CD}^{2} 5^{+}$Foxp3 ${ }^{+}$regulatory T (E), and NK1.1 $1^{+} \mathrm{CD}^{-}$NK (F) cells within spleens and inguinal LNs in tumor-free WT and $B L N K^{-1-}$ mice were determined by immunofluorescent staining followed by flow cytometric analysis ( $n=6$ for each group). Histograms represent means \pm SEM. Significant differences between sample means. Similar results were obtained from two independent experiments. ${ }^{* *} P<0.01$. 
in $B L N K^{-1-}$ mice were well correlated because numbers of inguinal $\mathrm{LN}$ cells did not differ significantly between $B L N K^{-1-}$ mice and $\mathrm{WT}$ mice. Inguinal $\mathrm{LN} \mathrm{CD} 4^{+}, \mathrm{CD} 8^{+}$, and $\mathrm{CD} 4{ }^{+} \mathrm{CD} 25^{+} \mathrm{Foxp}^{+}$cell numbers in $B L N K^{-1-}$ mice were increased by $(2.1 \pm 0.4) \times 10^{5}$ cells $(P<0.01)$, $(1.7 \pm 0.3) \times 10^{5}$ cells $(P<0.001)$, and $(2.5 \pm 0.4) \times 10^{5}$ cells $(P<0.001)$ over WT mice, respectively (Figure $2, \mathrm{D}$ and $\mathrm{E})$. No significant difference was observed in the numbers of inguinal $\mathrm{LN} \mathrm{NK} 1.1^{+} \mathrm{CD}^{-} \mathrm{NK}$ cells (Figure $2 \mathrm{~F}$ ).
These results suggest the possibility that the alterations in lymphocyte populations may contribute to the attenuation of tumor immunity in $B L N K^{-1-}$ mice.

Numbers of Infiltrating T and B Cells in B16F10 Melanoma Tumors Decrease in $\mathrm{BLNK}^{-/-}$Mice

$\mathrm{CD} 4{ }^{+} \mathrm{CD} 25^{+} \mathrm{Foxp}^{+}{ }^{+}$regulatory $\mathrm{T}$ cells inhibit immune responses mediated by $\mathrm{CD} 4^{+} \mathrm{CD} 25^{-}$and $\mathrm{CD} 8^{+} \mathrm{T}$ cells
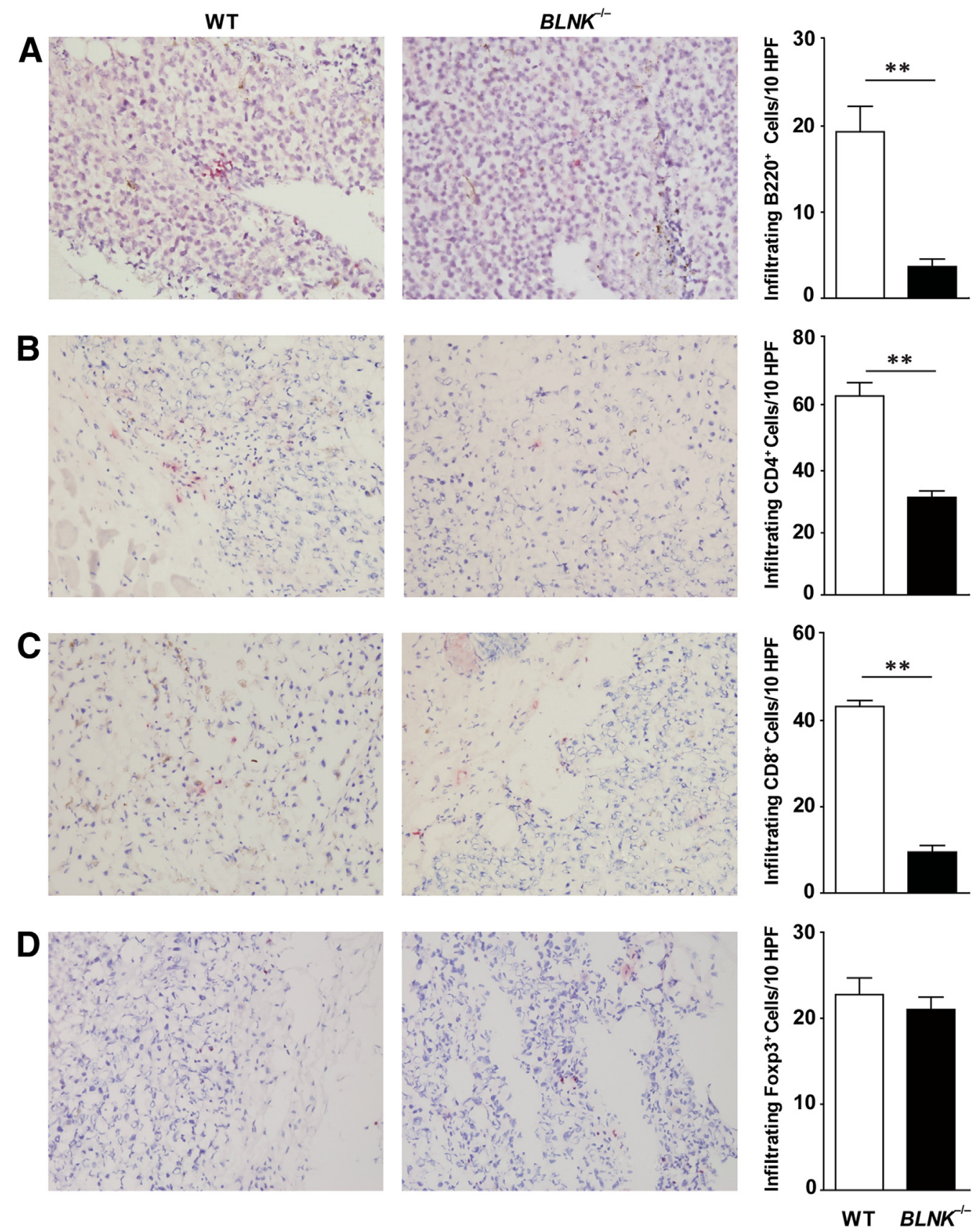

Figure 3 The numbers of B and T cells infiltrating into B16F10 melanoma tumors decrease in $B L N K^{-/-}$mice. WT and $B L N K^{-/-}$mice were inoculated s.c. in the right flank with $1.0 \times 10^{6} \mathrm{~B} 16 \mathrm{~F} 10$ cells. The s.c. B16F10 melanomas were harvested on day 11 after inoculation. Representative IHC images and numbers of ${\mathrm{B} 220^{+}(\mathrm{A}), \mathrm{CD}^{+}(\mathrm{B}), \mathrm{CD}^{+}(\mathrm{C}) \text {, and Foxp3 }}^{+}$(D) cells. The cells were stained red to differentiate from brown of the melanin pigment. Data were obtained from four mice in each group. Significant differences between sample means. Similar results were obtained from three independent experiments. ${ }^{* *} P<0.01$. Original magnification, $\times 200$ (A-D). HPF, high-power field. 
in vitro via contact-dependent and cytokine-independent mechanisms, ${ }^{18-20}$ and affect the development and progression of tumor growth. ${ }^{21}$ We used IHC to quantitate B220 $\mathrm{B}, \mathrm{CD}^{+} \mathrm{T}, \mathrm{CD} 8^{+} \mathrm{T}$, and Foxp $3^{+}$regulatory $\mathrm{T}$ cells infiltrating into s.c. primary B16F10 melanoma tumors on day 11 after inoculation. The numbers of $\mathrm{B} 220^{+} \mathrm{B}, \mathrm{CD} 4^{+} \mathrm{T}$, and $\mathrm{CD} 8^{+} \mathrm{T}$ cells in tumors were significantly decreased in $B L N K^{-1-}$ mice compared with WT mice (Figure 3, A-C), although no significant difference was seen in the number of Foxp $3^{+}$regulatory $\mathrm{T}$ cells in tumors (Figure 3D). This is despite increased numbers of lymph node $\mathrm{CD} 4^{+}$and $\mathrm{CD} 8^{+}$ $\mathrm{T}$ cells in $B L N K^{-1-}$ mice (Figure 2D). Taken together, these results suggest that the differences in tumor immunity observed between WT and $B L N K^{-1-}$ mice are not due to regulatory $\mathrm{T}$ cells, and raise the possibility that $\mathrm{B}$ cells promote T-cell infiltration into B16F10 melanoma tumors.

\section{Adoptive Transfer of B Cells into $B L N K^{-/-}$Mice Improves Animal Survival and Attenuates B16F10 Melanoma Growth}

To investigate whether $\mathrm{B}$ cells promote tumor immunity against B16F10 melanoma, we evaluated the effect of adoptive transfer of $\mathrm{B}$ cells into $B L N K^{-1-}$ mice on tumor immunity. We found that B16F10 melanoma growth was significantly diminished in reconstituted $B L N K^{-1-}$ mice compared with $B L N K^{-1-}$ mice, and was comparable to tumor growth observed in WT mice (Figure 4A). Moreover, survival of reconstituted $B L N K^{-1-}$ mice was improved compared with unreconstituted $B L N K^{-l-}$ mice (Figure $4 \mathrm{~B}$ ). In addition, IHC analyses revealed increased numbers of $\mathrm{B} 220^{+} \mathrm{B}, \mathrm{CD} 4^{+} \mathrm{T}$, and $\mathrm{CD}^{+} \mathrm{T}$ cells infiltrating into tumors in reconstituted $B L N K^{-1-}$ mice compared with $B L N K^{-1-}$ mice (Figure 5, $\mathrm{A}-\mathrm{C})$. Notably, no significant differences were observed in the number of Foxp $3^{+}$regulatory T cells infiltrating into tumors between reconstituted $B L N K^{-1-}$ mice and $B L N K^{-1-}$ mice (Figure 5D). These results indicate that $B$ cells attenuate the growth of $\mathrm{B} 16 \mathrm{~F} 10$ melanoma by promoting $\mathrm{CD}^{+}$and $\mathrm{CD}^{+} \mathrm{T}$-cell infiltration into tumors.

\section{B Cells Are Required for Cytokine Production by Tumor-Infiltrating T cells}

A previous study showed that the presence of B cells enhances T-cell cytokine production in vitro. ${ }^{11}$ Thus, we assessed the cytokine production of tumor-infiltrating lymphocytes (TILs) in WT, $B L N K^{-1-}$, and reconstituted $B L N K^{-/-}$mice on day 11 after inoculation. TILs were stained for cell surface CD3, CD4, CD8, and NK1.1 as well as intracellular IFN- $\gamma$, TNF- $\alpha$, and $\mathrm{GrB}$ expression, and analyzed by flow cytometry.

The phenotypes of the TILs included $\mathrm{CD}^{+} \mathrm{CD}^{+} \mathrm{T}$, $\mathrm{CD}^{+} \mathrm{CD}^{+} \mathrm{T}$, and $\mathrm{CD} 3^{-} \mathrm{NK} 1.1^{+} \mathrm{NK}$ cells. Percentages of IFN- $\gamma-$ secreting $\mathrm{CD}^{+} \mathrm{T}$ cells and IFN- $\gamma-$ and TNF- $\alpha-$ secreting $\mathrm{CD}^{+} \mathrm{T}$ cells were significantly decreased in $B L N K^{-I-}$ mice compared with WT mice (Figure 6, A and B), whereas percentages of TNF- $\alpha$-secreting $\mathrm{CD} 4^{+} \mathrm{T}$ cells and
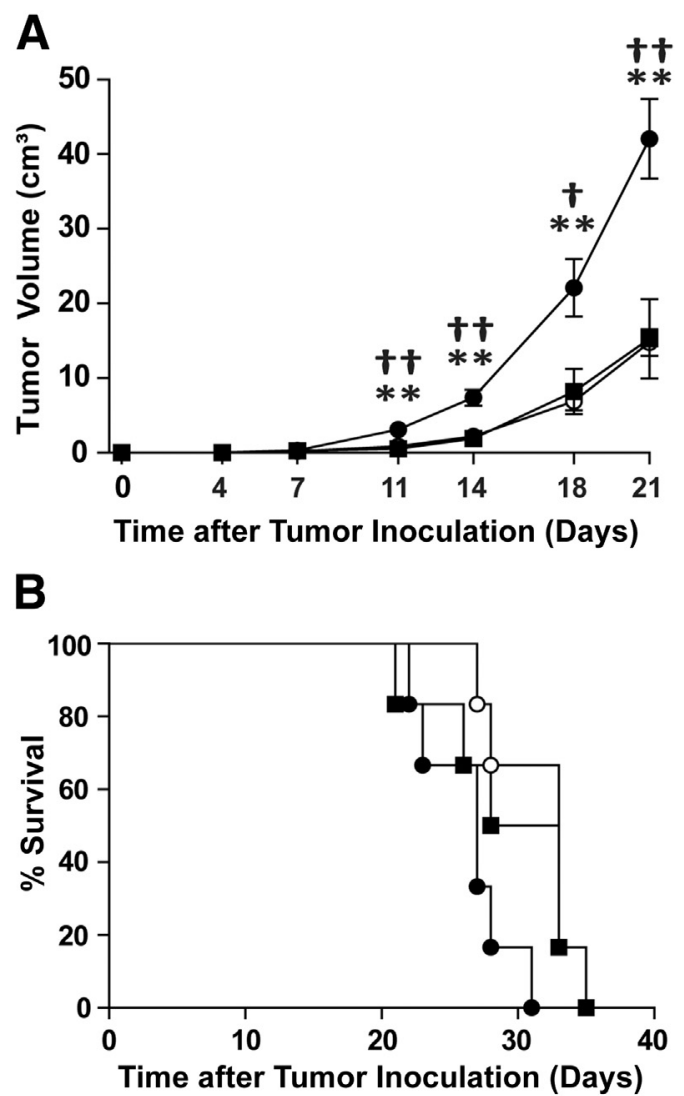

Figure 4 B16F10 melanoma growth in $B L N K^{-/-}$mice is attenuated by adoptive transfer of WT $B$ cells. For reconstituted $B L N K^{-1-}$ mice, purified $B$ cells $\left(1.0 \times 10^{7}\right)$ from WT mice were transferred into $B L N K^{-1-}$ mice by means of i.v. injection 1 day before tumor inoculation. WT (white circles), $B L N K^{-1-}$ (black circles), and reconstituted $B L N K^{-1-}$ mice (black squares) were inoculated s.c. on the right flank with $1.0 \times 10^{6}$ B16F10 cells. A: Means \pm SEM tumor volumes on the indicated days after B16F10 melanoma inoculation ( $n=6$ for each group). Significant differences between means for the same days. B: Survival of mice after B16F10 melanoma inoculation ( $n=6$ for each group). Similar results were obtained from three independent experiments. ${ }^{* *} P<0.01$ for WT mice versus $B L N K^{-1-}$ mice; ${ }^{\dagger} P<0.05,{ }^{\dagger} P<0.01$ for WT mice versus reconstituted $B L N K^{-1-}$ mice.

GrB-secreting NK1.1 $1^{+} \mathrm{CD}^{-} \mathrm{NK}$ cells were similar in both $B L N K^{-1-}$ and WT mice (Figure 6, A and C). Interestingly, percentages of IFN $-\gamma-$ secreting CD $4^{+} \mathrm{T}$ cells and IFN $-\gamma-$ and TNF- $\alpha-$ secreting $\mathrm{CD}^{+} \mathrm{T}$ cells in reconstituted $B L N K^{-1-}$ mice were improved compared with unreconstituted $B L N K^{-1-}$ mice (Figure 6, A and B). Furthermore, cytokine production by TILs correlated with the B16F10 melanoma growth and animal survival in WT, $B L N K^{-1-}$, and reconstituted $B L N K^{-1-}$ mice. Therefore, cytokine production is an important factor contributing to the attenuation of tumor immunity in $B L N K^{-1-}$ mice. In addition, these results suggest that $B$ cells are required for T-cell cytokine production in the tumor microenvironment.

\section{Discussion}

Initial studies of mouse tumor models using B-celldeficient $\mu$ MT mice suggested B cells negatively regulate 

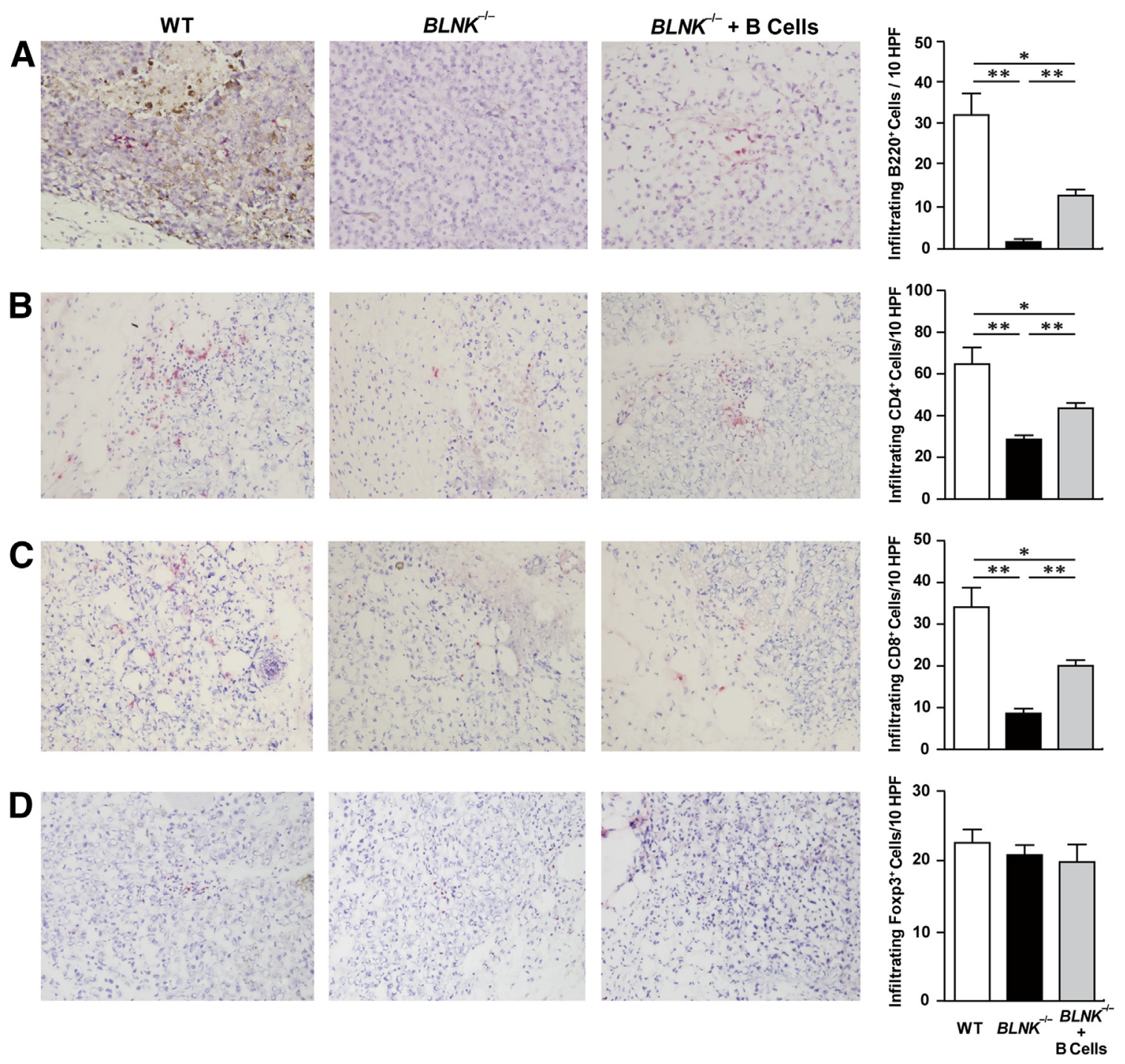

Figure 5 The numbers of B and T cells infiltrating into B16F10 melanoma tumors significantly increase in reconstituted $B L N K^{-1-}$ mice compared with $B L N K^{-1-}$ mice. For reconstituted $B L N K^{-1-}$ mice, purified $B$ cells $\left(1.0 \times 10^{7}\right)$ from WT mice were transferred into $B L N K^{-1}$ mice by means of i.v. injection 1 day before tumor inoculation. WT, $B L N K^{-1-}$, and reconstituted $B L N K^{-1-}$ mice were inoculated s.c. on the right flank with $1.0 \times 10^{6}$ B16F10 cells. The s.c. B16F10 melanoma tumors were harvested on day 11 after inoculation. Representative IHC images and numbers of B220 $0^{+}(\mathbf{A}), \mathrm{CD}^{+}(\mathbf{B}), \mathrm{CD}^{+}(\mathbf{C})$, and Foxp3 $3^{+}(\mathbf{D})$ cells. The cells were stained red to differentiate from brown of the melanin pigment. Data were obtained from four mice in each group. Significant differences between sample means. Similar results were obtained from three independent experiments. ${ }^{\star} P<0.05,{ }^{*} P<0.01$. Original magnification, $\times 200(\mathbf{A}-\mathbf{D})$. HPF, high-power field.

tumor immunity by inhibiting anti-tumor T-cell responses., In contrast, other murine tumor studies in which B cells were depleted by anti-CD20 mAb showed that B cells help to promote anti-tumor responses. ${ }^{11}$ The current study investigates the role of $\mathrm{B}$ cells in tumor immunity using $B L N K^{-1-}$ mice, which exhibit severely impaired development and function of B cells. ${ }^{12-16}$ The results show that tumor immunity against $\mathrm{B} 16 \mathrm{~F} 10$ melanoma tumors in $B L N K^{-/-}$mice is attenuated.

The conflicting results regarding the function of B cells in tumor immunity may be attributable to the activation status of B cells in different model systems. For example, resting B cells impair dendritic cell-induced tumor immunity, whereas CD40L-activated B cells do not. ${ }^{22}$ B-cell-deficient $\mu \mathrm{MT}$ mice lack both resting and activated B cells, which could potentially yield conflicting results depending on the extent of B-cell activation in a particular model system. Most tumor-infiltrating B cells (TIL-Bs) are activated by antigen exposure in cancer-bearing patients, as evidenced by Ig class switching, somatic hypermutation, and oligoclonality. ${ }^{23}$ In our model, B16F10 melanoma growth was suppressed in $B L N K^{-1-}$ mice reconstituted with WT B cells (Figure 4), suggesting that the state of TIL-B activation induced by B16F10 melanoma is favorable to tumor immunity.

Furthermore, in $B L N K^{-/-}$mice, a few mature $\operatorname{IgM}^{\mathrm{lo}} \operatorname{IgD}{ }^{\mathrm{hi}}$ $\mathrm{B}$ cells are found in the periphery, and T-cell development and function are both normal. Adult $B L N K^{-/-}$mice (8 to 13 weeks old), which we used in the current study, have 

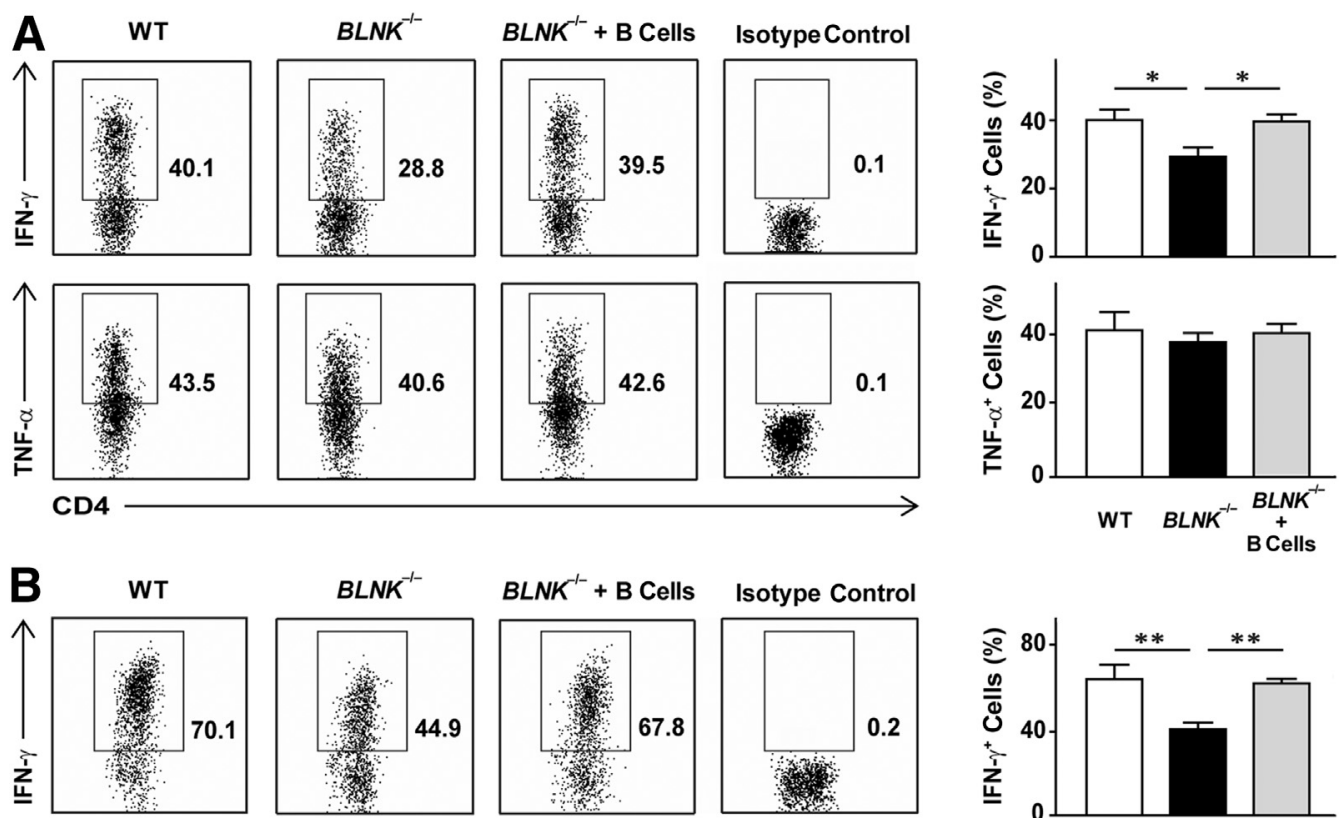

Isotype Control
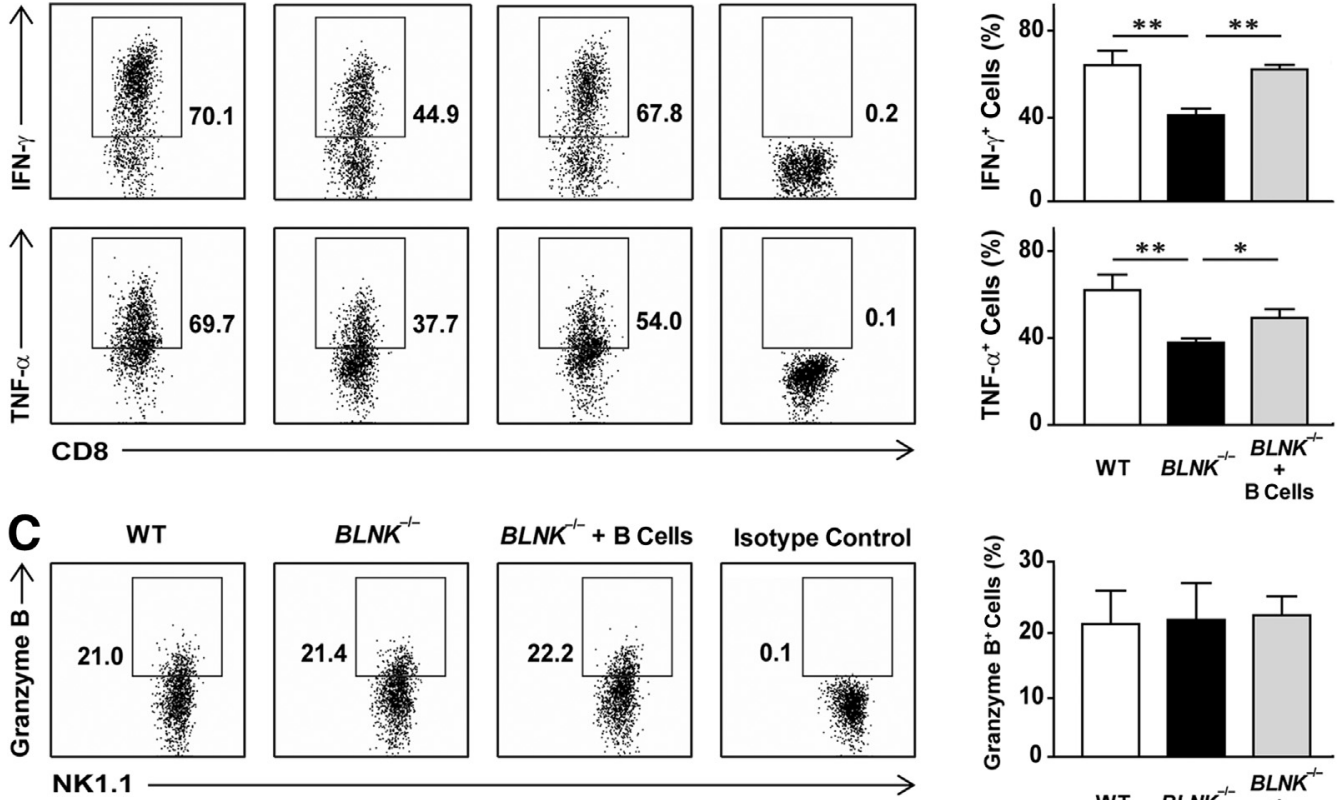

NK1.1
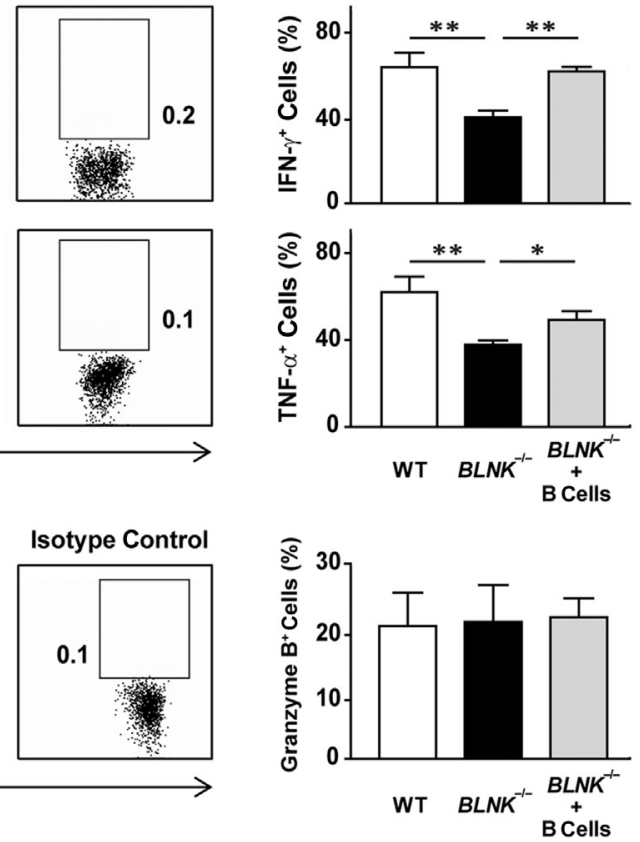

Figure 6 Cytokine production by TILs in WT, $B L N K^{-1-}$, and reconstituted $B L N K^{-1-}$ mice on day 11 after inoculation. A and B: TILs were stimulated in vitro with phorbol myristate acetate (PMA) and ionomycin for 4 hours in the presence of brefeldin A followed by staining for CD4 and CD8 and intracellular IFN- $\gamma$ and TNF- $\alpha$. C: TILs were stained in vitro for CD3, NK1.1, and intracellular granzyme B. Data were obtained from four mice in each group. Significant differences between sample means. Similar results were obtained from two independent experiments. ${ }^{*} P<0.05,{ }^{*} P<0.01$.

increased numbers of $\mathrm{B} 220^{+} \mathrm{IgM}^{+} \mathrm{B}$ cells compared with younger $B L N K^{-1-}$ mice (3 to 6 weeks old). ${ }^{14}$ Regarding lymphoid architecture, the numbers of splenocytes in $B L N K^{-/-}$mice are, on average, only three times less than in WT mice and the spleens contain lymphoid follicles that consist of B220 ${ }^{+}$B cells (Figure $2 \mathrm{~A}$ ). Thus, $B L N K^{-1-}$ mice have a few mature $\mathrm{B}$ cells in the periphery, normal $\mathrm{T}$ cells, and partially similar lymphoid architecture to WT mice. By contrast, in $\mu \mathrm{MT}$ mice, T-cell receptor diversity is significantly reduced and Th1 immune responses are enhanced. ${ }^{7,8}$ The size of spleens in $\mu \mathrm{MT}$ mice is, on average, six times smaller than in WT mice, and there is an absence of mature B cells in the periphery. ${ }^{24}$ Thus, it seems that in $B L N K^{-1-}$ mice, T-cell repertoire, T-cell function, and lymphoid tissue architecture are established in an environment more similar to WT mice than occurs in $\mu \mathrm{MT}$ mice. These critical differences between $B L N K^{-/-}$and $\mu \mathrm{MT}$ mice are the most likely explanations for the opposing findings between our study and previous studies using $\mu \mathrm{MT}$ mice.

On the other hand, it was previously reported that an ability of B cells to negatively regulate antitumor immune responses was attributed to B-cell provision of IL- $10 .{ }^{25}$ The B-cell subset that produces IL-10 was recently identified as regulatory B cells (Bregs), and we have confirmed that the ability of Bregs to produce IL-10 is impaired in $B L N K^{-1-}$ mice. ${ }^{16}$ Our current work does not eliminate the possibility of an inhibitory role for Bregs during tumor immune responses, but it does support the notion that the positive regulatory functions of $\mathrm{B}$ cells are dominant in this context.

TIL-Bs are an important component of the B-cell response to cancer $^{1,26}$; however, their significance in solid tumors remains unclear. In ovarian cancers, Dong et $\mathrm{al}^{27}$ 
state that TIL-Bs are associated with a worse outcome. Another study indicated that tumor-infiltrating IL-21-induced $\mathrm{GrB}^{+} \mathrm{B}$ cells play an immunosuppressive role in certain tumors by suppressing T-cell proliferation via GrB-dependent degradation of the T-cell receptor (TCR) $\zeta$-chain, a known GrB substrate. ${ }^{28,29}$ On the other hand, Milne et $\mathrm{al}^{30}$ showed that the presence of TIL-Bs is positively correlated with survival. In this regard, tumors containing both $\mathrm{CD}^{+}$and $\mathrm{CD} 20^{+}$ TILs are associated with higher survival than tumors containing either $\mathrm{CD}^{+}$or $\mathrm{CD} 20^{+}$TILs alone, ${ }^{30}$ suggesting that positive cooperative interactions between $\mathrm{CD}^{+}$and $\mathrm{CD} 20^{+}$ TILs are necessary for tumor immunity.

In the current study, the percentages of IFN- $\gamma-$ secreting $\mathrm{CD}^{+} \mathrm{T}$ cells and IFN- $\gamma-$ and $\mathrm{TNF}-\alpha-$ secreting $\mathrm{CD} 8^{+}$ $\mathrm{T}$ cells infiltrating into tumors were found to be significantly decreased in $B L N K^{-1-}$ mice, and were restored in reconstituted $B L N K^{-1-}$ mice (Figure 6, A and B). A previous study demonstrated that $\mathrm{B}$ cells are required for $\mathrm{T}$-cell cytokine production in vitro. ${ }^{11}$ In addition, it is also known that activated $\mathrm{B}$ cells can contribute to $\mathrm{CD} 4^{+}$T-cell priming through engagement of their antigen receptors. ${ }^{31}$ Taken together, our results indicate that TIL-Bs contribute to tumor immunity by promoting $\mathrm{CD}^{+}{ }^{+}$and $\mathrm{CD}^{+}$T-cell cytokine production in the tumor microenvironment. Although little is known about the mechanisms by which TIL-Bs promote favorable outcomes in cancer, several possibilities have been suggested, such as the production of cytokines and function of these cells as APCs. ${ }^{1}$

$B$ cells can present antigens more efficiently than other APCs by selectively presenting cognate antigens (Ags) collected through surface Ig molecules, which allows presentation of even low concentrations of Ags to T cells. ${ }^{32-35}$ In the case of weakly immunogenic tumors, such as B16F10 melanoma, B cells and other APCs are involved in optimal T-cell expansion. ${ }^{11}$ Nielsen et $\mathrm{al}^{23}$ showed that TIL-Bs are antigenexperienced B cells and express cell surface markers characteristic of APCs, such as major histocompatibility complex class I and class II molecules, as well as costimulatory molecules, such as CD80 and CD86. Accordingly, most tumorinfiltrating $\mathrm{T}$ cells show an activated effector phenotype. Intriguingly, $\mathrm{CD}^{+}$and $\mathrm{CD} 20^{+} \mathrm{TILs}$ are frequently seen in close proximity, often in loosely structured aggregates. ${ }^{23}$

Another study showed that advanced ovarian cancers lack intratumoral dendritic cells and instead contain TIL-Bs in close association with $\mathrm{T}$ cells. ${ }^{30}$ These studies suggest a positive role for TIL-Bs as APCs, thereby sustaining the survival and proliferation of tumor-infiltrating $\mathrm{T}$ cells over the long-term. In addition, the transfer of CD40L-activated tumor peptide-loaded B cells induces Ag-specific antitumor immune responses in mice via cross presentation of Ag to APCs and via direct T-cell activation, ${ }^{9}$ whereas $B L N K^{-1-}$ B cells show diminished responses to anti-CD40 stimulation. $^{12-15}$ Taken together, the function of $B L N K^{-1-}$ $\mathrm{B}$ cells as APCs in our model is likely impaired, resulting in decreased infiltration of activated $\mathrm{CD} 4^{+}$and $\mathrm{CD}^{+} \mathrm{T}$ cells into tumors.
To prove that B cells serve as APCs in tumor immunity, it will be necessary to clarify their antigen specificity and assess recognition by tumor-infiltrating T cells. Prior studies in medullary breast cancer identified two antigens recognized by recombinant antibodies derived from TIL-Bs: ganglioside D3 and $\beta$-actin. The latter was identified by virtue of exposure of $\beta$-actin on the surface of apoptotic tumor cells. $^{36,37}$ In lung cancer, target Ags of TIL-Bs include TP53, as well as many self-Ags that are overexpressed in tumor tissue. ${ }^{38}$ These studies suggest that TIL-B responses reflect a breakdown of tolerance to self-proteins, possibly due to apoptosis of tumor cells. Melanoma antigens recognizable by TIL-Bs in our model have not been identified, although it is known that glycoprotein 100 and melanoma antigen recognized by $\mathrm{T}$ cells- 1 are melanomaassociated antigens recognized by $\mathrm{T}$ cells. ${ }^{39,40}$ On the other hand, Moutai et $\mathrm{al}^{41}$ showed the transfer of $\mathrm{B}$ cells specific for a surrogate tumor Ag [hen egg lysozyme (HEL)] suppressed metastasis and growth of B16 melanoma cells transfected with a membrane-anchored form of the HEL expression vector (B16-mHEL). Therefore, we have already started to investigate the antigen specificity of TIL-Bs. Identification of additional antigens recognized by TIL-Bs may yield further insights into the mechanisms by which B-cell responses are triggered and contribute to tumor immunity.

In conclusion, our study supports the argument that B cells positively regulate tumor immune responses. ${ }^{1,11}$ Our findings strongly suggest that B cells contribute to tumor immunity by increasing the numbers of tumor-infiltrating $\mathrm{T}$ cells and promoting IFN- $\gamma$ and TNF- $\alpha$ production by $\mathrm{T}$ cells in the tumor microenvironment. Therefore, optimization of these B-cell functions could be important for cancer immunotherapies. It remains unclear which underlying characteristics of B cells, such as antigen specificity, are critical during tumor immunity. Further investigation into the function of TIL-Bs will be required to facilitate the design of more effective immunotherapies for the treatment of cancer.

\section{Acknowledgments}

We thank Masako Matsubara and Yuko Yamada for technical assistance.

\section{References}

1. Nelson BH: CD20+ B cells: the other tumor-infiltrating lymphocytes. J Immunol 2010, 185:4977-4982

2. Lampropoulou V, Calderon-Gomez E, Roch T, Neves P, Shen P Stervbo U, Boudinot P, Anderton SM, Fillatreau S: Suppressive functions of activated B cells in autoimmune diseases reveal the dual roles of Toll-like receptors in immunity. Immunol Rev 2010, 233: $146-161$

3. Bouaziz JD, Yanaba K, Tedder TF: Regulatory B cells as inhibitors of immune responses and inflammation. Immunol Rev 2008, 224: $201-214$ 
4. Mauri C, Gray D, Mushtaq N, Londei M: Prevention of arthritis by interleukin 10-producing B cells. J Exp Med 2003, 197:489-501

5. Shah S, Divekar AA, Hilchey SP, Cho HM, Newman CL, Shin SU, Nechustan H, Challita-Eid PM, Segal BM, Yi KH, Rosenblatt JD: Increased rejection of primary tumors in mice lacking $\mathrm{B}$ cells: inhibition of anti-tumor CTL and TH1 cytokine responses by B cells. Int J Cancer 2005, 117:574-586

6. Qin Z, Richter G, Schüler T, Ibe S, Cao X, Blankenstein T: B cells inhibit induction of T cell-dependent tumor immunity. Nat Med 1998, 4:627-630

7. João C, Ogle BM, Gay-Rabinstein C, Platt JL, Cascalho M: B celldependent TCR diversification. J Immunol 2004, 172:4709-4716

8. Moulin V, Andris F, Thielemans K, Maliszewski C, Urbain J, Moser M: B lymphocytes regulate dendritic cell (DC) function in vivo: increased interleukin 12 production by DCs from B cell-deficient mice results in T helper cell type 1 deviation. J Exp Med 2000, 192: 475-482

9. Ritchie DS, Yang J, Hermans IF, Ronchese F: B-lymphocytes activated by CD40 ligand induce an antigen-specific anti-tumour immune response by direct and indirect activation of CD8(+) T-cells. Scand J Immunol 2004, 60:543-551

10. Crawford A, Macleod M, Schumacher T, Corlett L, Gray D: Primary T cell expansion and differentiation in vivo requires antigen presentation by B cells. J Immunol 2006, 176:3498-3506

11. DiLillo DJ, Yanaba K, Tedder TF: B cells are required for optimal $\mathrm{CD} 4+$ and $\mathrm{CD} 8+\mathrm{T}$ cell tumor immunity: therapeutic B cell depletion enhances B16 melanoma growth in mice. J Immunol 2010, 184: 4006-4016

12. Pappu R, Cheng AM, Li B, Gong Q, Chiu C, Griffin N, White M, Sleckman BP, Chan AC: Requirement for B cell linker protein (BLNK) in B cell development. Science 1999, 286:1949-1954

13. Jumaa H, Wollscheid B, Mitterer M, Wienands J, Reth M, Nielsen PJ: Abnormal development and function of B lymphocytes in mice deficient for the signaling adaptor protein SLP-65. Immunity 1999, 11: 547-554

14. Minegishi Y, Rohrer J, Coustan-Smith E, Lederman HM, Pappu R, Campana D, Chan AC, Conley ME: An essential role for BLNK in human B cell development. Science 1999, 286:1954-1957

15. Hayashi K, Nittono R, Okamoto N, Tsuji S, Hara Y, Goitsuka R, Kitamura D: The B cell-restricted adaptor BASH is required for normal development and antigen receptor-mediated activation of B cells. Proc Natl Acad Sci U S A 2000, 97:2755-2760

16. Jin G, Hamaguchi $Y$, Matsushita T, Hasegawa M, Le Huu D, Ishiura N, Naka K, Hirao A, Takehara K, Fujimoto M: B-cell linker protein expression contributes to controlling allergic and autoimmune diseases by mediating IL-10 production in regulatory B cells. J Allergy Clin Immunol 2013, 131:1674-1682

17. Le Huu D, Matsushita T, Jin G, Hamaguchi Y, Hasegawa M, Takehara K, Fujimoto M: IL-6 blockade attenuates the development of murine sclerodermatous chronic graft-versus-host disease. J Invest Dermatol 2012, 132:2752-2761

18. Sakaguchi S: Regulatory T cells: key controllers of immunologic selftolerance. Cell 2000, 101:455-458

19. Dieckmann D, Plottner H, Berchtold S, Berger T, Schuler G: Ex vivo isolation and characterization of $\mathrm{CD} 4(+) \mathrm{CD} 25(+) \mathrm{T}$ cells with regulatory properties from human blood. J Exp Med 2001, 193:1303-1310

20. Shevach EM: CD4+CD25+ suppressor T cells: more questions than answers. Nat Rev Immunol 2002, 2:389-400

21. Kobayashi N, Hiraoka N, Yamagami W, Ojima H, Kanai Y, Kosuge T, Nakajima A, Hirohashi S: FOXP3+ regulatory T cells affect the development and progression of hepatocarcinogenesis. Clin Cancer Res 2007, 13:902-911

22. Watt V, Ronchese F, Ritchie D: Resting B cells suppress tumor immunity via an MHC class-II dependent mechanism. J Immunother 2007, 30:323-332

23. Nielsen JS, Sahota RA, Milne K, Kost SE, Nesslinger NJ, Watson PH, Nelson BH: CD20+ tumor-infiltrating lymphocytes have an atypical
CD27- memory phenotype and together with CD8 $+\mathrm{T}$ cells promote favorable prognosis in ovarian cancer. Clin Cancer Res 2012, 18: 3281-3292

24. Asano MS, Ahmed R: CD8 T cell memory in B cell-deficient mice. J Exp Med 1996, 183:2165-2174

25. Inoue S, Leitner WW, Golding B, Scott D: Inhibitory effects of B cells on antitumor immunity. Cancer Res 2006, 66:7741-7747

26. Coronella-Wood JA, Hersh EM: Naturally occurring B-cell responses to breast cancer. Cancer Immunol Immunother 2003, 52:715-738

27. Dong HP, Elstrand MB, Holth A, Silins I, Berner A, Trope CG, Davidson B, Risberg B: NK- and B-cell infiltration correlates with worse outcome in metastatic ovarian carcinoma. Am J Clin Pathol 2006, 125:451-458

28. Lindner S, Dahlke K, Sontheimer K, Hagn M, Kaltenmeier C, Barth TF, Beyer T, Reister F, Fabricius D, Lotfi R, Lunov O, Nienhaus GU, Simmet T, Kreienberg R, Möller P, Schrezenmeier H, Jahrsdörfer B: Interleukin 21-induced granzyme B-expressing B cells infiltrate tumors and regulate T cells. Cancer Res 2013, 73:2468-2479

29. Wieckowski E, Wang GQ, Gastman BR, Goldstein LA, Rabinowich H: Granzyme B-mediated degradation of T-cell receptor zeta chain. Cancer Res 2002, 62:4884-4889

30. Milne K, Köbel M, Kalloger SE, Barnes RO, Gao D, Gilks CB, Watson PH, Nelson BH: Systematic analysis of immune infiltrates in high-grade serous ovarian cancer reveals CD20, FoxP3 and TIA-1 as positive prognostic factors. PLoS One 2009, 4:e6412

31. Rodríguez-Pinto D: B cells as antigen presenting cells. Cell Immunol 2005, 238:67-75

32. Bouaziz JD, Yanaba K, Venturi GM, Wang Y, Tisch RM, Poe JC, Tedder TF: Therapeutic B cell depletion impairs adaptive and autoreactive CD4+ T cell activation in mice. Proc Natl Acad Sci U S A 2007, 104:20878-20883

33. Rivera A, Chen CC, Ron N, Dougherty JP, Ron Y: Role of B cells as antigen-presenting cells in vivo revisited: antigen-specific B cells are essential for $\mathrm{T}$ cell expansion in lymph nodes and for systemic $\mathrm{T}$ cell responses to low antigen concentrations. Int Immunol 2001, 13:1583-1593

34. Xiu Y, Wong CP, Bouaziz JD, Hamaguchi Y, Wang Y, Pop SM, Tisch RM, Tedder TF: B lymphocyte depletion by CD20 monoclonal antibody prevents diabetes in nonobese diabetic mice despite isotypespecific differences in Fc gamma $\mathrm{R}$ effector functions. J Immunol 2008, 180:2863-2875

35. Batista FD, Neuberger MS: Affinity dependence of the B cell response to antigen: a threshold, a ceiling, and the importance of off-rate. Immunity 1998, 8:751-759

36. Hansen MH, Nielsen H, Ditzel HJ: The tumor-infiltrating B cell response in medullary breast cancer is oligoclonal and directed against the autoantigen actin exposed on the surface of apoptotic cancer cells. Proc Natl Acad Sci U S A 2001, 98:12659-12664

37. Kotlan B, Simsa P, Teillaud JL, Fridman WH, Toth J, McKnight M, Glassy MC: Novel ganglioside antigen identified by B cells in human medullary breast carcinomas: the proof of principle concerning the tumor-infiltrating B lymphocytes. J Immunol 2005, 175:2278-2285

38. Yasuda M, Mizukami M, Hanagiri T, Shigematsu Y, Fukuyama T, Nagata Y, So T, Ichiki Y, Sugaya M, Takenoyama M, Sugio K, Yasumoto K: Antigens recognized by $\operatorname{IgG}$ derived from tumor-infiltrating $\mathrm{B}$ lymphocytes in human lung cancer. Anticancer Res 2006, 26:3607-3611

39. Bakker AB, Schreurs MW, de Boer AJ, Kawakami Y, Rosenberg SA, Adema GJ, Figdor CG: Melanocyte lineage-specific antigen gp100 is recognized by melanoma-derived tumor-infiltrating lymphocytes. J Exp Med 1994, 179:1005-1009

40. Kawakami Y, Eliyahu S, Sakaguchi K, Robbins PF, Rivoltini L, Yannelli JR, Appella E, Rosenberg SA: Identification of the immunodominant peptides of the MART-1 human melanoma antigen recognized by the majority of HLA-A2-restricted tumor infiltrating lymphocytes. J Exp Med 1994, 180:347-352

41. Moutai T, Yamana H, Nojima T, Kitamura D: A novel and effective cancer immunotherapy mouse model using antigen-specific B cells selected in vitro. PLoS One 2014, 9:e92732 